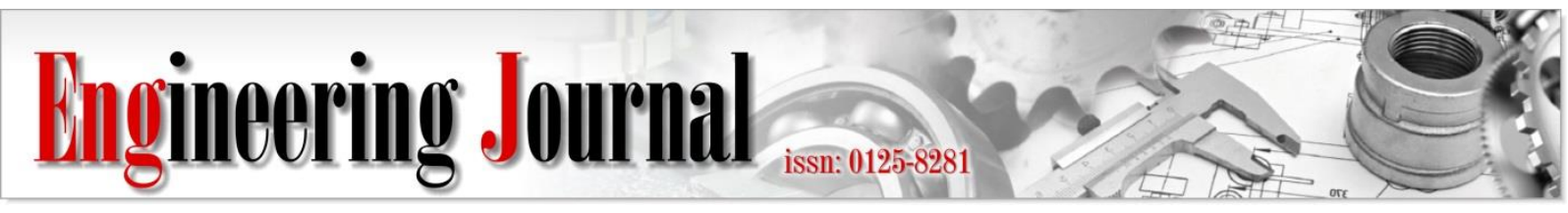

Article

\title{
Problems Causing Delays and Risk Factors in Welding Construction Projects of Thailand
}

\author{
Asa Prateepasen ${ }^{1, \mathrm{a}}$ and Adisak Aumpiem ${ }^{2, \mathrm{~b}, *}$ \\ 1 Department of Production Engineering, Faculty of Engineering, King Mongkut's University of \\ Technology Thonburi (KMUTT), Thailand \\ 2 Industrial and Manufacturing Systems Engineering, Faculty of Engineering, King Mongkut's University of \\ Technology Thonburi (KMUTT), Thailand \\ E-mail: aasa.pra@kmutt.ac.th, b,*aumpiem@gmail.com (Corresponding author)
}

\begin{abstract}
Welding delays are one of the major risks in steel construction industry in Thailand. Therefore, it is essential to study and analyze the risk factors that lead to problems causing welding construction delays. This studied focused on delay risk factors in causes of construction projects collected from literature review having the different construction processes, project period, culture, countries, and amount of delay factors for contribution in welding construction projects. Questionnaire surveys and interviews were conducted on major companies connected to welding works in support of the construction projects in Thailand to survey thought problems causing delays and risk factors. Risk factors related to internal and external risk were rated among the risks identified problems. Issues such as material receiving, performance, qualified and language barriers were also highlighted in the questionnaire and during interviews. Notably, the problem such as "multilingual and multicultural" caused ineffective communication. A case study used the FMEA technique to analyze the severity, occurrences and detection, and evaluate to risk priority number. Significant risks were analyzed and compared between the Modified RPN and WRPN method for finding the "Critical risk". The new finding can contribute additional help for project managers to predict and mitigate welding construction project delays.
\end{abstract}

Keywords: Delay risk, Thailand, fabrication risk, welding risk, construction.

ENGINEERING JOURNAL Volume 25 Issue 5

Received 29 July 2020

Accepted 12 April 2021

Published 31 May 2021

Online at https://engj.org/

DOI:10.4186/ej.2021.25.5.33 


\section{Introduction}

Delay risk has a negative effect on a project on stakeholders in terms of growth in relationships, management and include legal problems have always been one of the major problems in the construction industry [14]. Normally, when the project is delayed, it necessarily accelerated or extended time leading to incurring cost overrun, quality or production reduction [5-7]. Its effect extends to include the stockholder in terms of arbitration, dispute and litigation. Delay can be defined as an incident or action that extends the time required to complete the project identified in a contract. The key factors impacting delays in the construction project can be classified delay into excusable compensable, excusable non-compensable and non-compensable delays while Dhananjay K.,2015 divided that problem causing of delays are related factors mainly in Consultant, Contractor, Client, Material, Labor and equipment. Meanwhile in the steel construction project were related "welding activities" are a sufficient factor in the projects and one mostly risk factors that lead to the project delays due to inadequate quality, safety, engineering design and procurement systems.

Thailand is becoming a newly industrialized country. The construction industry is the main sector for the growth of the countries general economy and investment opportunities [3]. Steel construction industry is in one category of construction industries and fabrication exports, that have "welding activity" are primarily works. The problem causing welding construction project delay in Thailand related to engineering designers, clients, subcontractors and were rated among the top problems [8]. Among many problems that welding construction projects face Thailand include construction materials, human resources, technology and technical skills/knowledge [9]. Welding is across disciplinary technique widely used in steel construction projects in Thailand such as offshore/onshore construction, boiler $\&$ pressure vessel, shipbuilding, pipelines, and within many other fields. The importance of welding for the construction industry at the present time is unquestionable and it is difficult even to imagine the welding construction projects operating without risk assessment and the quality of the project is satisfactory. Most researches studies examining the problem causing construction project delays meanwhile in Thailand, few researchers study and mainly focus on welding construction projects.

This study was literature reviews both outside the region and focused on Asia regional researches for finding problem causing of delay, gap contribution, prepared a questionnaire and interviews. All of these were applied to studies in welding construction projects in Thailand. New and up-to-date investigation address the problems causing risks, the main risk factors of welding in project delay, and accumulation contributing a range of risk, assess the risks and prioritize them to be mitigated appropriately, contributing to the knowledge and deployment of the critical risks that should be taken into consideration for welding construction project in Thailand and developing countries.

\section{Theoretical Background and Literature Review}

Thailand, called "Center" of Asean Economic Community (AEC) is located in the heart of Southeast Asia. AEC was established in December 2015 between 10 member states. Construction industry sector is one of the important sectors that contributes to and promotes Thailand's economic growth. In 2017, according to the IMF [10], Thailand had a GDP of US\$ 455 billion, The economy is expected to post $4.1 \%$ growth in 2018 and 8 th largest economy in Asia [11].

Doing business 2020 starting a business score

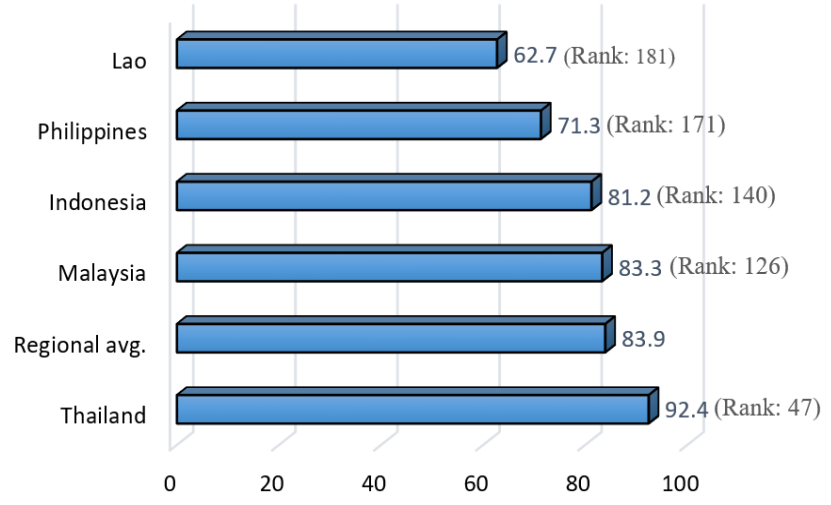

Fig. 1. Ranking and score of starting a business in Thailand.

It was reported that Thailand was ranked $1^{\text {st }}$ in Asia and 47 of 190 economies on the ease of starting a business. This is determined by sorting their scores for starting a business shown in Fig. 1 [11]. The construction industry including the steel fabrication project is the main sector for developing the country. It is essential to study and analyze the risk factors that lead to problems such as welding construction project delays in Thailand.

Previous studies were reviewed in the project risks in terms of delay risk in the construction projects. The growing application of risk management and quality controls in welding both as a regulatory and contractual requirement as a management discipline has had a significant impact on welding, the importance of the delay in construction projects. Delay and risk assessment in the construction project has been a research topic for decades. Many researchers have studied the causes and effects of project delay. The cost overrun and time delay in their project and country through studies, questionnaires survey and in-depth interviews with experts personal in construction project [2, 12-14]. 


\subsection{Problems Causing Construction Delays and Literature Reviews}

The delay risk has been one of the primary problems in the construction industry $[1,2,4,15]$. Normally, when the project is delayed, the spread time or accelerated its lead the way incur additional cost $[3,14]$. The excusable compensable, excusable non-compensable and noncompensable are the three key factors impacting delay in the project [1]. Risk analysis is about developing an understanding of the risk. Descriptive statistics methods of organizing namely "relative importance index, RII" were used to finding the relative importance of attributes perceived by the respondents $[3,16,17]$. Cronbach's alpha is a tool test used to estimate the internal consistency or reliability, of a composite score. Constructs' reliability is satisfied when Cronbach's ' $\alpha$ ' coefficient value exceeds 0.7 $[12,18]$. One of the risk assessment techniques that is used through analysis in this research is the Failure Mode and Effect Analysis technique.

FMEA is a technique in ISO31010 [19, 20] for managing high priority risk factors for mitigation or preventing the work problem leading to the failures and minimizing the incidence by evaluates failure modes of severity, occurrence and detection [15, 21-24]. Islam and Suhariadi [15] surveyed to identify project delays in Bangladesh by identified 60 risk factors. They present that the primary causes of schedule delay in Bangladesh found in huge building projects were attributed to that a construction manager lacks experience in the construction project, which is a root cause of schedule delay. This was similar to the highest risk of delay problem found in UAE [4], Vietnam [25, 26] and Taiwan [27].

The high-risk ranked factors found in Bangladesh had insignificant impacts on construction projects in Korea [12], Benin [28] and Egypt [29]. Clearly, the factors of significant events cannot be considered common across the countries [2]. Zou and Zhang [13] studied surveys and findings on risk factors in China construction and parallel surveys in the Australian construction industry and found the main key risks that clients, designers and government bodies should manage the risk and work cooperatively. $\mathrm{He}$ also identified the risk sufficient index score of staff member attempt in the improvement of a project while the risk importance index (RII) method used to determine the rank of each item(effect) in Pakistan [9], Malaysian [3].

The risk assessment technique of ISO31010 was used to evaluate, analyze and improve the delay risks in welding construction projects [30]. Kang and Sun [31] conducted risk assessment through a modified FMEA named correlation-FMEA. They suggested in the fabrication and marine operations were aspects of realistic weather criteria of particular importance. Park et al. [12] studied risk factors and assessment in Korean companies by modified RPN method of each factor as a multiplication of importance, Severity (S), Occurrence (O), Detection (D) found that payment delays and project delays are the two most critical risk factors affecting construction management companies [32]. Aumpiem and Prateepasen
[33] studied the FMEA and brainstorming technique to reduce the course and effect in discoloration of piping welding with duplex materials which help the productivity, quality of the project in the pipeline welding fabrication work. Pandey and Sharma [34] studied the model of various risks in potential modes of failure. AHP, FMEA and WRPN have been applied and calculated which he proposed an approach based on the combination of wellestablished methodologies. Saaty in 1980 was introduced the Analytic Hierarchy Process (AHP), which is a technique for organizing and multi-criteria decision analysis based on mathematics composed of two steps is determined the relative weights and rankings(priority) [7]. This study was a literature review and focused on Asia regional research for application in this study. Summary critical risks reviewed, the gap of this literature and risk technique used as shown in Table 1. Moreover, some of the risk factors utilized are risk factors in the questionnaire.

\subsection{Problems Causing in Welding Construction Project}

Welding is a process that uses fusion to connect materials together which is used in many industries and it is the main of the principal activities in modern fabrication, shipbuilding, boiler\& pressure vessel offshore/onshore industry. The performance of these industries regarding product quality, delivery schedule, productivity and economy depends upon structure design, production planning, welding technology [35]. Failure of welded construction steel components can occur due to design imposed, management control, the performance of welding, wrong steel choice, working environment or quality controls $[36,37]$. Fatigue strength in welding is one of the strength problems which affect the design of contemporary ship's structures [38]. The contractor's financial capability is the highest delay risk including the inadequacy of experience or capability of contractors lead to the delay risk factors in an offshore platform, the subsea pipeline of an oil \& gas projects [39].

\section{Research Methodology}

To address the objectives stated above, this study was separated into three parts: First, review literature related to the critical risk factors are influences on typical project delays, period project, culture, countries and factors are the root cause of delayed project which focused in Asia region of the offshore/onshore construction projects, boiler \& pressure vessel, and shipbuilding in Thailand construction projects. For design, a questionnaire and interviews were used to collect data for implementation and applicability in the welding construction project. 
Table 1. The literature review focused on Asia regional of delay, risk factors and finding the gap contribution.

\begin{tabular}{|c|c|c|c|}
\hline Researches & $\begin{array}{c}\text { Country } \\
\text { of studied }\end{array}$ & Major of risk factors effective in delays & Gap of literature \\
\hline $\begin{array}{c}\text { Islam, } \\
2018 \text { [15] }\end{array}$ & Bangladesh & $\begin{array}{l}\text { 1) Lack of experienced construction } \\
\text { manager } \\
\text { 2) Lowest bidder selection } \\
\text { 3) Fund shortage by owner } \\
\text { 4) Lack of proper management } \\
\text { 5) Improper planning and scheduling }\end{array}$ & $\begin{array}{l}\text { - Schedule delay is the main reason for project failure. } \\
\text { - Owner, consultants and contractors are no significant } \\
\text { variation of respondents by Kruskal-Wallis Test } \\
\text { - Identifies the responsibility of major stakeholders } \\
\text { - Focused on the privately large building projects }\end{array}$ \\
\hline $\begin{array}{c}\text { Park et al., } \\
2017 \text { [12] }\end{array}$ & Korea & $\begin{array}{l}\text { 1) Payment delay } \\
\text { 2) Legal dispute with a client } \\
\text { 3) Customer dissatisfaction with field service } \\
\text { 4) Contract revocation }\end{array}$ & $\begin{array}{l}\text { - Investigate risk factors critical to project execution. } \\
\text { - Risk analysis methods using AHP and FMEA } \\
\text { - Interviews the top } 15 \text { Korean CM firms } \\
\text { - Project and \& Payment delays are the most critical risk factors }\end{array}$ \\
\hline $\begin{array}{c}\text { Fallahnejad, } \\
2013 \text { [40] }\end{array}$ & Iran & $\begin{array}{l}\text { 1) Low ability to provide or imported } \\
\text { material } \\
\text { 2) Unrealistic contract durations imposed } \\
\text { 3) Material by the client is slow delivery } \\
\text { 4) Slow land expropriation }\end{array}$ & $\begin{array}{l}\text { - Identify and rank the causes of delay in Iran } \\
\text { - } 10 \text { experts, } 43 \text { questionnaires in studies } \\
\text { - Imported material is most important is delay project } \\
\text { - RII finding importance factor and Spearman Test used finding } \\
\text { the correlation coefficient }\end{array}$ \\
\hline $\begin{array}{l}\text { Gardezi, } \\
2013 \text { [9] }\end{array}$ & Pakistan & $\begin{array}{l}\text { 1) Law and Order Situation } \\
\text { 2) Design is changes } \\
\text { 3) Unsuitable availability of Funds with } \\
\text { Client } \\
\text { 4) War \& Terrorism } \\
\text { 5) Insignificant knowledge of site } \\
\text { management }\end{array}$ & $\begin{array}{l}\text { - Identify the delays that result in time extension factors } \\
\text { - Identified } 27 \text { factors are significant contributions to time } \\
\text { extensions } \\
\text { - The funds' incentives can adopt lowering the effects of delays }\end{array}$ \\
\hline $\begin{array}{c}\text { Doloi, } \\
2012 \text { [2] }\end{array}$ & India & $\begin{array}{l}\text { 1) Vendors delivery materials delay } \\
\text { 2) Drawing/design not available on time } \\
\text { 3) Contractor has financial constraints } \\
\text { 4) Scope of work has increase } \\
\text { 5) Obtaining permissions from local } \\
\text { authorities }\end{array}$ & $\begin{array}{l}\text { - The most important cause of a contractor is Financial } \\
\text { problem } \\
\text { - Key factors affecting time performance occurred from } \\
\text { inefficient site management } \\
\text { - Lack of commitment is a top-five of factor analysis } \\
\text { - SPSS tool to use estimated the extent of correlation among } \\
\text { various variables. }\end{array}$ \\
\hline $\begin{array}{l}\text { Marzouk } \\
\text { and El- } \\
\text { Rasas, } 2014 \\
\text { [29] }\end{array}$ & Egypt & $\begin{array}{l}\text { 1) Owner completed work the Finance and } \\
\text { payments } \\
\text { 2) Owner changes the scope during } \\
\text { construction } \\
\text { 3) Subsurface conditions is affected } \\
\text { 4) Labors are low productivity level }\end{array}$ & $\begin{array}{l}\text { - In the study was analyzed and compared to the most } \\
\text { important } \\
\text { delay. } \\
\text { - Statistical analysis is accomplish using analysis of variance } \\
\text { ANOVA method to test delay causes. } \\
\text { - Material related, Shortage of construction materials in the } \\
\text { market are highest severity index }\end{array}$ \\
\hline $\begin{array}{c}\text { Han, } \\
2009[4]\end{array}$ & Korea & $\begin{array}{l}\text { 1) Owner is low ability to handle the mega } \\
\text { projects } \\
\text { 2) Project path is a lot of variations } \\
\text { 3) Not suitable in the delivery system of the } \\
\text { project } \\
\text { 4) Inappropriate to the time managing tools } \\
\text { 5) Change orders carry out the complexity of } \\
\text { an express railway }\end{array}$ & $\begin{array}{l}\text { - The analysis discovered five major delay causes for railway } \\
\text { - Suggests lessons learned to better prepare and potential causes } \\
\text { of time delays } \\
\text { - Project managers should consider various social and } \\
\text { political factors in addition to time, cost, quality and cost. }\end{array}$ \\
\hline
\end{tabular}


Table 1 The literature review focused on Asia regional of delay, risk factors and finding the gap contribution (continues)

\begin{tabular}{|c|c|c|c|}
\hline Researches & $\begin{array}{c}\text { Country of } \\
\text { studied }\end{array}$ & Major of risk factors effective in delays & Gap of literature \\
\hline $\begin{array}{l}\text { Le-Hoai, } \\
2008 \text { [26] }\end{array}$ & Vietnam & $\begin{array}{l}\text { 1) Site management and Supervision is } \\
\text { inferior } \\
\text { 2) Inferior assistance of project management } \\
\text { 3) Owner has Financial difficulties } \\
\text { 4) Contractor has financial difficulties } \\
\text { 5) Changes of design }\end{array}$ & $\begin{array}{l}\text { - Comparison among countries of delay and cost overruns } \\
\text { - A comparison of various selected construction industries in } \\
\text { Africa and Asia } \\
\text { - Index Analysis and Spearman's Rank Correlation used } \\
\text { - Poor site management and supervision controls are most } \\
\text { frequent, severe and important causes }\end{array}$ \\
\hline $\begin{array}{c}\text { Sambasivan, } \\
2007 \text { [3] }\end{array}$ & Malaysia & $\begin{array}{l}\text { 1) Time over expansion } \\
\text { 2) Cost over expansion } \\
\text { 3) Arguments } \\
\text { 4) Arbitration } \\
\text { 5) Litigation }\end{array}$ & $\begin{array}{l}\text { - } 150 \text { respondents, } 28 \text { different factors and } 6 \text { most effected of } \\
\text { delay } \\
\text { - RII and ranking of categories were identified by Clients, } \\
\text { Consultants, Contractors } \\
\text { - Contractor's improper planning and time overrun is cause } \\
\text { and effect of the delay }\end{array}$ \\
\hline $\begin{array}{c}\text { Zou, } \\
2007 \text { [13] }\end{array}$ & China & $\begin{array}{l}\text { 1) Project funding problems } \\
\text { 2) Variations by the client } \\
\text { 3) Price inflation of construction materials } \\
\text { 4) Program scheduling was inadequate } \\
\text { 5) Difficulty in reimbursement for } \\
\text { Contractor's }\end{array}$ & $\begin{array}{l}\text { - Studies key risks in the construction projects } \\
\text {-The findings risk factors by parallel survey in Australian and } \\
\text { China } \\
\text { - Risks category were related to clients, contractors, } \\
\text { subcontractors, designers and government agencies }\end{array}$ \\
\hline
\end{tabular}

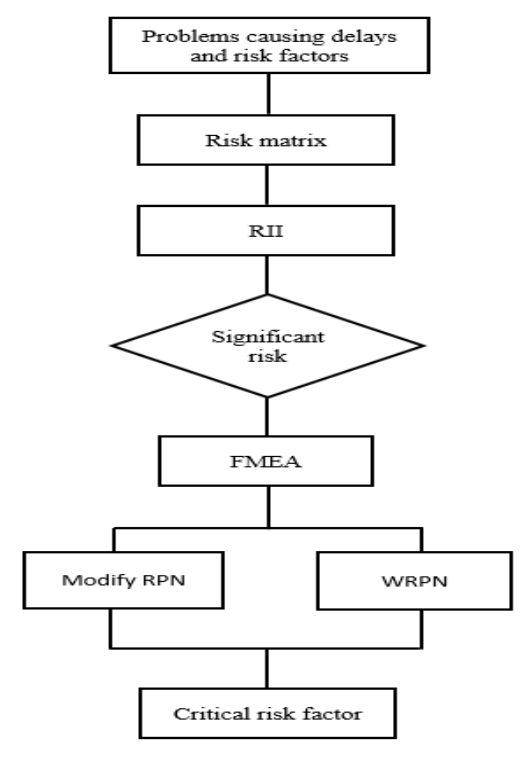

Fig. 2. The model of study in problems causing delays and risk factors.

Second, a risk matrix was used during risk assessment to define the level of risk by considering the category of severity against the category of impact as shown in Eq. (1) and applicable to find the relative importance index (RII) values which give the ranking score. The top ten of RII are shown the "significant risks", to be analyzed by the FMEA technique. FMEA was applied to assess the risks of delay using three criteria is occurrence, detection and severity evaluated to define the risk priority numbers (RPN) by 13 construction experts e.g. welding managers, senior welding engineers and project managers are working in welding construction projects. The mean value evaluation showed the average of a data set and Cronbach's was used to determine the relative variance, reliability and internal consistency of the questionnaire and analysis tool use SPSS and MS. Finally, the RPN applicable to the Modified RPN and WRPN method of the significant risk for comparing and finding the "critical risk factors" which is a priority to be considered for elimination or mitigation in welding construction projects of Thailand. The model of this study is shown in Fig. 2.

\subsection{Preparation of the Questionnaire}

After the literature review, a questionnaire list was developed based on previous studies and literature research in Vietnam, UAE, China, Malaysia, Pakistan, Korea, Turkey, and Thailand $[3,5,13,16,17,41]$. The face-to-face interviews were conducted with owners, fabricators, engineering and managers in construction industries. Before distributing the questionnaire were sent to the perceptions of construction experts in welding 
construction company through review the questionnaire in conveying the variables applicable for Thailand and all the respondents affirmed that the survey was adequate to the causes of delay risk in the welding construction project. The construction experts recommend that the language barrier may be one factor through effective delay risk.

The questionnaire survey comprehensive 43 potential delay factors were distributed to representative sample in the welding construction company. The questionnaire was divided into significant are four parts. The first part was intended to background and general information due to the respondent's profile such as sex, age, education and experience in working. The second part requested background information about a business company, business category and average project size. The third part requested the understanding of background in risk management standards, risk tools, and quality control systems. Some data of the third part will be use study in future research and the fourth part focused on the risk factors related to the delay in welding construction projects which is a key of this study.

\subsection{Questionnaire Survey Responses}

The targeted respondents were selected from the Department of Business Development of Thailand (DBD) which directs to the welding construction industry. The sampling method used convenience and snowball sampling. This method is chosen when it is difficult to receive a response from the sample elements chosen at random. A questionnaire was distributed through our friends working in the welding construction company in Thailand. This sampling method assisted us to get completed questionnaires quickly [3].

The questionnaire response was completed and returned through personal email. The respondents were asked to evaluate their delay risk (Probability and Impact) in construction project management practices based on the Likert scale used. The Likert scale of $1-5$ points was selected to obtain the probability and impact of the delay risk factors in the construction projects. The probability of each factor has been evaluated by adopting a five-point scale of 1 to $5[42,43]$. These numerical qualities are to the respondents' where 1 represented "rare", 2 "occasional", 3 "somewhat frequent", 4 "frequent", and 5 "very frequent". Likewise, the impact of each delay risk factors was adopted, where 1 represented "very low", 2 "low", 3 "moderate", 4 "high", and 5 "very high."

\subsection{Delay Risk Identify}

\subsubsection{Risk assessment technique}

The criteria are utilized in deciding whether the leave of hazard is high or low. The probability $(\mathrm{P})$ of an unfortunate event and the level of reality of the impact(I). The several criteria were involved for risk identification may be one or more methods. Therefore, multi-criteria for risk identified are needed. This research used a mathematical description of each risk factor using a 5point Likert scale $[43,44]$. The delay risk for each risk was calculated Eq. (1).

$$
\mathrm{R}=\mathrm{P} \times \mathrm{I}
$$

The delay risk level was conducted from the survey data using probability and impact which the value resulted of each delay factor and each respondent calculate is risk identify. The risk identified range is divided into five risk range scales, where $\mathrm{n} 1=1-5, \mathrm{n} 2=6-10, \mathrm{n} 3=11-15, \mathrm{n} 4=16-$ 20 and $n 5=21-25$ see in Table $3 . \mathrm{N}$ is the amount of respondents is 78 . The collected data were analyzed using SPSS Statistics 24 and MS Excel software which value resulted through using find the relative importance index in the next step.

\subsubsection{Relative importance index (RII)}

The RII to evaluate the relative importance factor of the various cause and effects of the delay. The risk identified result 78 respondents from the mathematical method in Eq. (1) to be used for calculating finding a relative importance index method in Eq. (2).

$$
\mathrm{RII}=\frac{\sum w}{A N}=\frac{5 n_{5}+4 n_{4}+3 n_{3}+2 n_{2}+1 n_{1}}{5 N}
$$

Based on the observed result from the risk identified, RII was calculated for each risk by SPSS software. The resulted are presented. Table 3 showed all the delay risks are significant 43 risk items in construction projects. Which the top 10 most relative important factors of delay risk in the welding construction industry in Thailand based on risk rating. The highest mean value (average) is 2.641 and the lowest is 1.192 of delay factors. The top ten of delay risk was to investigate and FMEA analysis next step.

\subsubsection{Modified RPN and weighted risk priority number (WRPN)}

The modified RPN was identified for each factor by multiplication importance of severity, occurrence and detection in Eq. (3), while the weighted risk priority number method was evaluated and identified by the weight of parameter of each factor though the priority is focused on S, O and D, given by Xiao and Huang [45] as shown in Eq. (4)

$$
\text { Modified RPN = RII x RPN }
$$

$$
\text { WRPNi }=\text { RPNi } \times \mathrm{f}(\mathrm{Wi})=\mathrm{Si} \times \text { Oi } \times \text { Di } \mathrm{x}(\mathrm{Wi}) \quad i \neq 0
$$

\subsubsection{Reliability analysis and FMEA analysis}

The top ten of the highest delay risks were performed reliability before the FMEA technique. We also performed a reliability analysis and define risk priority factors. All 13 Thailand construction experts, in senior management level 
personnel were interviews intended used deeper experience knowledge to identify the problems in the current delay risk management practices of Thailand welding construction industry and define representative risk factors. The face-to-face interviews were analyzed for the severity, occurrence, and detection of the top ten delay risk factors based on applied FMEA techniques which the interviewed analysis resulted for perform the risk priority number (RPN).

The reliability analysis of the top ten delay factors through 13 welding construction experts was analyzed by comparing between Modified RPN technique and WRPN technique. The Cronbach's alpha reliability analysis in risk factors was rectify using it is a technique a widely used approach to measure internal consistency and determine the factor of consistency [41, 46]. The Cronbach's alpha coefficient, a dependability measure for interior consistency that takes a value between zero and one, was processed utilizing the following in Eq. (5)

$$
\alpha=\left(\frac{k}{k-1}\right)\left(\frac{\sum_{i=1}^{k} \sigma_{i}^{2}}{\sigma_{t}^{2}}\right)
$$

where $\alpha=$ Cronbach's alpha; $\sigma_{i}^{2}=$ the variance in total; ; $\sigma_{i}^{2}=$ variance of component, $\mathrm{k}=$ the number of risk factors and $i=$ higher Cronbach's alpha coefficient. In general, the score 0.8-0.9 is considered desirable and the score is $0.6-0.7$ acceptable.

It is calculated by multiplying the severity(S), occurrence $(\mathrm{O})$ and detection(D) of each risk factor using a 5-point Likert scale resulting in a scale from 1 to 125 as following Eq. (5). The next stage in this study calculated the RPN of each delay factor (top ten of RII delay factors) by modified RPN version. Which a modified RPN method is calculated by multiplication of RII, S, O and D as following Eq. (6).

$$
\begin{gathered}
\mathrm{RPN}=\mathrm{S} \times \mathrm{O} \times \mathrm{D} \\
\text { Modified RPN }=\text { RII } \times \mathrm{S} \times \mathrm{O} \times \mathrm{D}
\end{gathered}
$$

The failure mode is defined as when the RPN score is greater than the risk criterion and is considered as an unacceptable risk, while a score lower than the risk criterion is called acceptable. This score is varied based on the delay risk in construction projects. In studies was statistics calculates the relationship between $\mathrm{S}, \mathrm{O}$ and $\mathrm{D}$ of top ten factors are shown in Table 2.

\subsubsection{Improvement risk priority based on WRPN}

As we described in section 3.3.3, The RPN is the relative importance of $\mathrm{S}, \mathrm{O}$ and $\mathrm{D}$. Previously all items have been analyzed and assigned with RPN value. The construction experts were asked to make a comparison between Severity (Sw1), Occurrence (Ow2) and Detectability (Dw3). For the study case was investigate, The AHP values provided by construction experts form experienced are Sw1 compare with Dw3 = 30:70, Ow2 compare with $\mathrm{Sw}_{\mathrm{w}} 1=60: 40$ and Dw3 compare with Ow2 $=60: 40$. The improvement risk priority is based on WRPN instead of RPN as following Eq. (8).

$$
\mathrm{WRPN}=(\mathrm{S} \times \beta \mathrm{S})+(\mathrm{S} \times \beta \mathrm{O})+(\mathrm{S} \times \beta \mathrm{D})
$$

AHP is one of the main mathematical treatments of decision problems, currently available to support the decision theory. AHP is the identification of suspects by observers in project delay cases. AHP was evaluated in the importance of factors and used to calculated is carried out weighting factor of severity $(\beta S=0.48)$, the weighting factor of occurrence $(\beta \mathrm{O}=0.21)$ and a weighting factor of detectability $(\beta D=0.31)$. The WRPN score is then calculated by using Eq. (9). Table 4 shows the analysis result of this study's modified RPN method compared with the WRPN method, and the risk score is shown to be the highest risk of the method.

\section{Data Analysis and Result}

All of the risks observed in the questionnaire can occur in any construction project. The objective of the studies is to obtain information about risk factors to identify the key risk that can significantly and critically influence risk management in construction projects of Thailand.

\subsection{Data Analysis Approach}

All respondents' works involved in construction projects. In this survey research, 150 questionnaires were distributed and sent to construction companies for identification of risk factors of those companies. The 83 questionnaires were received after excluding the inadequate responses of the questionnaires. Only 78 full responses were used to obtain data on the accomplished and useful for analysis. The 78 respondents gave a valid responses rate of $53.3 \%$, of which the 52 respondents worked in local firms and 26 respondents worked in international firms.

Of the 78 respondents, $26.92 \%$ had ages between 31 35 years, $61.54 \%$ worked in engineering, $16.67 \%$ had more than 20 years experience, $66.67 \%$ are in the local company, and all respondents worked directly to the welding construction project. The work experience and especially in huge construction projects was the focus of this study. This questionnaire found the international company has acknowledgment in risk assessment more than the local company which the risk assessment of work leading to risk management is systematic.

Cronbach's alpha value of this investigated for severity, occurrence and detection by SPSS. The result value of evaluated to range from 0.926 to 0.937 that the resulted is "acceptable reliability" shown in Table 2 . The 43 delay risk factors were calculated and analyzed based on the probability and impact in which the value calculated is the identified risk range of $\mathrm{n} 1$ to $\mathrm{n} 5$ shown in Table 3. 
The evaluation of the relative of RII found that "Delay of material supply by suppliers" is the highest delay risk in the welding construction project. This supports the findings by Fallahnejad [40] to provide imported material where the material delay was one of the key factors affecting time delay in Iran and India construction projects [23]. The top of delay factors: suppliers delay of material supply and drawings and documents are not issued on time have a RII score $=0.5282$, The change of design by owners have a RII score $=0.5205$ and the frequent changes by designers have a RII score $=0.4949$. One factor of interest in Thailand is a language barrier found RII score $=0.4256$ (16th). The lowest of the RII score $=$ 0.2385 is labor strikes and disputes. The implementing process for selecting good suppliers or renewed suppliers and including the management plan for issue a document by analyzing the factors is significant it leading to the effect of delay risk in construction projects decrease.

Table 2. Internal consistency of top ten of significant risk factors.

\begin{tabular}{lccc}
\hline \multirow{2}{*}{ Significant risk factor } & \multicolumn{3}{c}{ Cronbach's Alpha } \\
\cline { 2 - 4 } & Severity & Occurrence & Detection \\
\hline Delay of material supply & 0.929 & 0.932 & 0.928 \\
\hline $\begin{array}{l}\text { Drawings/documents are } \\
\text { not issued on time }\end{array}$ & 0.927 & 0.931 & 0.930 \\
\hline Change design required & 0.933 & 0.932 & 0.933 \\
\hline Frequent changes of design & 0.932 & 0.933 & 0.937 \\
\hline $\begin{array}{l}\text { Subcontractors' poor } \\
\text { performance }\end{array}$ & 0.932 & 0.932 & 0.929 \\
\hline Lack of qualified staff & 0.928 & 0.928 & 0.926 \\
\hline Contractors' incompetence & 0.928 & 0.929 & 0.928 \\
\hline $\begin{array}{l}\text { Drawings and } \\
\text { specifications is deficiencies }\end{array}$ & 0.926 & 0.930 & 0.927 \\
\hline $\begin{array}{l}\text { Unreasonably imposed } \\
\text { tight schedule of Owners }\end{array}$ & 0.933 & 0.936 & 0.929 \\
\hline \begin{tabular}{l} 
Defective design \\
\hline
\end{tabular} & 0.929 & 0.930 & 0.930 \\
\hline
\end{tabular}

Based on the modified RPNs shown in Table 4. The construction company should focus on the following delay risk factor in descending order of priority: the delay of material supply by suppliers(40.3), subcontractors' poor performance(40.1), drawings and documents are not issued on time(35.8), contractors' incompetence and lack of qualified staff (28.1), owners' unreasonably imposed tight schedule (27.1), change of design required by owners(23.3), frequent changes of design by designers(21.6), deficiencies in drawings and specifications(17.6) and Defective design(17.3).

Comparing the theory of modified RPN and WRPN technique shown in Table 4 . This study found that the top three delay risks from analysis of the welding construction project in Thailand obtained from both techniques provide the same ranking while the other level risk is the difference.

\section{Conclusions and Recommendations}

This study was presented with an up-to-date risk factor regarding the current welding construction project scenario and the risk factors trends for eliminated or mitigation risks of the overall welding construction project in Thailand. Problems causing delays and risk factors of the welding construction projects of this study survey show the top 10 significant risk factors from among the 43 risk factors. The findings showed that problems causing delays and risk factors of the top ten significant risk results reveal that the type of risk the internal be called "direct conversion delay" which implies the need to give more priority to reducing these types of critical delay risk while the top of external risk in $13^{\text {th }}$. The knowledge gap of the proposed study investigated the risk factors to the project execution plan in welding construction projects and ranked them using modified RPN and WRPN methods to develop the critical risk ranking. The separation between the risk analysis of modified RPN and WRPN method found the highest delay factors of the delay of materials as supply by suppliers is the highest critical delay risk which in 10th of the critical delay risk factor is different. The analysis result on the research of welding construction industry showed that the first of three, both modified RPN and WRPN techniques, was similarly in the delay of material supply by suppliers, subcontractors' poor performance, drawings \& documents not issued on time. The rankings in 4th-10th of both analysis techniques are different which may be from the project difference, cash flow and others. These problems were similar to the condition in several other developing countries such as UAE, China, Malaysia, Pakistan, Benin, Turkey, and India. So that, it found that the suppliers' delay of material supply is the most important cause of delay and one contribution gap in this research while the language barrier (RII rank=16) ineffective communication.

Finally, we found that the risk assessment by modified RPN and WRPN method have similar of three highest-ranked critical factors (1) delay of material supply by suppliers, (2) subcontractors' poor performance, and (3) drawings and documents are not issued on time are same the critical ranking. It is these generic and unique risks that influence the achievement of welding construction project objectives in Thailand. Further comparison of the previous studies risk found that they are mainly related to contractors, followed by clients, subcontractors and governmental. Presently not being managed systematically in welding construction projects because of (1) Inadequate of communication between packet engineer and site officer, (2) procurement lack of significant amount of bureaucracy, (3) change of responsibility from headquarters is to field, and (4) experience transfers to subcontractors. To eliminate risks appropriately, strategies to manage risks were sought from the perspectives of project stakeholders and life cycle under the Thailand industry background. 
Table 3. Type of risk categories, Average value and RII score of delay risk factors (Questionnaires).

\begin{tabular}{|c|c|c|c|c|c|c|c|c|c|c|c|}
\hline \multirow{2}{*}{$\begin{array}{l}\text { Delay risk } \\
\text { factors }\end{array}$} & \multirow{2}{*}{ Delay factors in construction } & \multicolumn{6}{|c|}{ Relative importance index factors } & \multirow{2}{*}{ RII } & \multirow{2}{*}{ Mean } & \multirow{2}{*}{$\begin{array}{l}\text { Type of } \\
\text { Risks }\end{array}$} & \multirow{2}{*}{ Rank } \\
\hline & & n1 & $\mathrm{n} 2$ & $\mathrm{n} 3$ & $\mathrm{n} 4$ & $\mathrm{n} 5$ & $\mathrm{~N}$ & & & & \\
\hline 1 & Change of design required by owners & 11 & 28 & 22 & 15 & 2 & 78 & 0.5205 & 2.603 & Internal & 3 \\
\hline 2 & Owners' unreasonably imposed tight schedule & 23 & 27 & 14 & 10 & 4 & 78 & 0.4590 & 2.295 & Internal & 9 \\
\hline 3 & Owners' improper intervention & 26 & 25 & 15 & 9 & 3 & 78 & 0.4410 & 2.205 & Internal & 11 \\
\hline 4 & Delayed payment to contractors by owner & 29 & 29 & 8 & 11 & 1 & 78 & 0.4103 & 2.051 & Internal & 18 \\
\hline 5 & Owner's lack of scope of work definition & 33 & 25 & 7 & 10 & 3 & 78 & 0.4077 & 2.038 & Internal & 19 \\
\hline 6 & Delays in obtaining site access and right of way & 41 & 22 & 8 & 5 & 2 & 78 & 0.3564 & 1.782 & Internal & 25 \\
\hline 7 & Breach of contracts and disputes by Owners' & 44 & 26 & 6 & 2 & 0 & 78 & 0.3128 & 1.564 & Internal & 31 \\
\hline 8 & Owners' sudden bankruptcy & 59 & 15 & 3 & 1 & 0 & 78 & 0.2615 & 1.308 & Internal & 39 \\
\hline 9 & Defective design & 25 & 27 & 13 & 10 & 3 & 78 & 0.4436 & 2.218 & Internal & 10 \\
\hline 10 & Deficiencies in drawings \& specifications & 15 & 37 & 13 & 10 & 3 & 78 & 0.4692 & 2.346 & Internal & 8 \\
\hline 11 & Frequent changes of design & 14 & 26 & 21 & 13 & 4 & 78 & 0.5154 & 2.577 & Internal & 4 \\
\hline 12 & Drawings and documents are not issued on time & 11 & 33 & 12 & 17 & 5 & 78 & 0.5282 & 2.641 & Internal & 2 \\
\hline 13 & Accidents during construction & 33 & 25 & 13 & 7 & 0 & 78 & 0.3846 & 1.923 & Internal & 22 \\
\hline 14 & Poor quality of work & 22 & 35 & 11 & 8 & 2 & 78 & 0.4282 & 2.141 & Internal & 14 \\
\hline 15 & Low productivity of labor \& equipment & 30 & 27 & 13 & 7 & 1 & 78 & 0.4000 & 2.000 & Internal & 20 \\
\hline 16 & Unpredicted the technical problems in construction & 22 & 37 & 9 & 9 & 1 & 78 & 0.4205 & 2.103 & Internal & 17 \\
\hline 17 & Contractors' incompetence & 17 & 32 & 15 & 13 & 1 & 78 & 0.4692 & 2.346 & Internal & 7 \\
\hline 18 & Lack of qualified staff & 20 & 29 & 12 & 14 & 3 & 78 & 0.4744 & 2.372 & Internal & 6 \\
\hline 19 & Subcontractor poor performance & 15 & 29 & 18 & 14 & 2 & 78 & 0.4949 & 2.474 & Internal & 5 \\
\hline 20 & Subcontractor breach of contracts \& disputes & 37 & 29 & 6 & 6 & 0 & 78 & 0.3513 & 1.756 & Internal & 26 \\
\hline 21 & Delay of material supply by suppliers & 11 & 26 & 22 & 18 & 1 & 78 & 0.5282 & 2.641 & Internal & 1 \\
\hline 22 & Quality problems of supplier materials & 18 & 38 & 12 & 10 & 0 & 78 & 0.4359 & 2.179 & Internal & 12 \\
\hline 23 & Language barrier & 24 & 30 & 15 & 8 & 1 & 78 & 0.4256 & 2.128 & External & 16 \\
\hline 24 & War threats and political instability & 54 & 16 & 6 & 0 & 2 & 78 & 0.2923 & 1.462 & External & 37 \\
\hline 25 & Labor strikes and disputes & 63 & 15 & 0 & 0 & 0 & 78 & 0.2385 & 1.192 & External & 43 \\
\hline 26 & Changes in laws and regulations & 57 & 17 & 3 & 1 & 0 & 78 & 0.2667 & 1.333 & External & 38 \\
\hline 27 & Corruption and bribes & 49 & 20 & 7 & 2 & 0 & 78 & 0.3026 & 1.513 & External & 33 \\
\hline 28 & Delays in approvals & 23 & 34 & 10 & 8 & 3 & 78 & 0.4308 & 2.154 & External & 13 \\
\hline 29 & Criminal acts & 60 & 16 & 1 & 1 & 0 & 78 & 0.2538 & 1.269 & External & 41 \\
\hline 30 & Substance abuse & 49 & 17 & 7 & 4 & 1 & 78 & 0.3205 & 1.603 & External & 28 \\
\hline 31 & Conflicts due to differences in culture & 62 & 12 & 3 & 1 & 0 & 78 & 0.2538 & 1.269 & External & 42 \\
\hline 32 & Inflation and sudden changes in prices & 48 & 24 & 5 & 1 & 0 & 78 & 0.2949 & 1.474 & External & 36 \\
\hline 33 & Currency fluctuation & 50 & 20 & 6 & 1 & 1 & 78 & 0.3000 & 1.500 & External & 35 \\
\hline 34 & Shortage in material supply and availability & 25 & 35 & 14 & 4 & 0 & 78 & 0.3923 & 1.962 & External & 21 \\
\hline 35 & Shortage in manpower supply and availability & 23 & 30 & 18 & 6 & 1 & 78 & 0.4256 & 2.128 & External & 15 \\
\hline 36 & Shortage in equipment availability & 29 & 32 & 12 & 4 & 1 & 78 & 0.3846 & 1.923 & External & 23 \\
\hline 37 & Unexpected inclement weather & 43 & 26 & 6 & 3 & 0 & 78 & 0.3205 & 1.603 & External & 29 \\
\hline 38 & Unforeseen site conditions & 55 & 22 & 1 & 0 & 0 & 78 & 0.2615 & 1.308 & External & 40 \\
\hline 39 & Delays in resolving contractual issues & 34 & 35 & 8 & 1 & 0 & 78 & 0.3385 & 1.692 & External & 27 \\
\hline 40 & Delays in resolving disputes & 43 & 26 & 6 & 3 & 0 & 78 & 0.3205 & 1.603 & External & 30 \\
\hline 41 & Unfairness in tendering & 30 & 32 & 12 & 4 & 0 & 78 & 0.3744 & 1.872 & External & 24 \\
\hline 42 & Local protectionism & 41 & 32 & 5 & 0 & 0 & 78 & 0.3077 & 1.538 & External & 32 \\
\hline 43 & Difficulty in claiming insurance compensation & 46 & 26 & 4 & 2 & 0 & 78 & 0.3026 & 1.513 & External & 34 \\
\hline
\end{tabular}


Table 4. Critical risks compared between the Modified RPN and WRPN method.

\begin{tabular}{|c|c|c|c|c|c|c|c|c|c|c|c|c|c|c|}
\hline \multirow{4}{*}{ Risk significant } & \multirow{4}{*}{$\begin{array}{l}\text { Type of } \\
\text { risk }\end{array}$} & \multirow{4}{*}{ RPN } & \multicolumn{6}{|c|}{ Modified RPN Calculate } & \multicolumn{6}{|c|}{ Weight Risk Priority Number (WRPN) } \\
\hline & & & \multirow{3}{*}{$S$} & \multirow{3}{*}{$\mathrm{O}$} & \multirow{3}{*}{$\mathrm{D}$} & \multirow{3}{*}{ RII } & \multirow{3}{*}{$\begin{array}{l}\text { Modified } \\
\text { RPN }\end{array}$} & \multirow{3}{*}{ Ranking } & \multirow{3}{*}{$\begin{array}{c}\beta \mathrm{S} \\
0.48 \\
\mathrm{~S}\end{array}$} & \multirow{3}{*}{$\begin{array}{c}\beta_{\mathrm{O}} \\
0.21 \\
\mathrm{O}\end{array}$} & \multirow{3}{*}{$\begin{array}{c}\beta_{\mathrm{D}} \\
0.31 \\
\mathrm{D}\end{array}$} & \multirow{3}{*}{ WRPN } & \multirow{3}{*}{$\begin{array}{c}\text { Critical } \\
\text { risk } \\
(\%)\end{array}$} & \multirow{3}{*}{ Ranking } \\
\hline & & & & & & & & & & & & & & \\
\hline & & & & & & & & & & & & & & \\
\hline $\begin{array}{l}\text { Delay of material supply } \\
\text { by suppliers }\end{array}$ & Internal & 40.36 & 4.00 & 2.85 & 3.54 & 0.528 & 21.31 & 1 & 4.0 & 2.9 & 3.5 & 3.616 & 15.42 & 1 \\
\hline $\begin{array}{l}\text { Subcontractors' poor } \\
\text { performance }\end{array}$ & Internal & 40.14 & 3.85 & 3.15 & 3.31 & 0.495 & 19.87 & 2 & 3.9 & 3.2 & 3.3 & 3.536 & 14.38 & 2 \\
\hline $\begin{array}{l}\text { Drawings and documents } \\
\text { are not issued on time }\end{array}$ & Internal & 35.80 & 3.69 & 3.08 & 3.15 & 0.528 & 18.90 & 3 & 3.7 & 3.1 & 3.2 & 3.395 & 13.68 & 3 \\
\hline Lack of qualified staff & Internal & 28.06 & 3.23 & 2.69 & 3.23 & 0.474 & 13.30 & 5 & 3.2 & 2.7 & 3.2 & 3.117 & 9.63 & 6 \\
\hline $\begin{array}{l}\text { Contractors' } \\
\text { incompetence }\end{array}$ & Internal & 28.13 & 3.54 & 2.46 & 3.23 & 0.469 & 13.19 & 4 & 3.5 & 2.5 & 3.2 & 3.217 & 9.55 & 4 \\
\hline $\begin{array}{l}\text { Owners' unreasonably } \\
\text { imposed tight schedule }\end{array}$ & Internal & 27.08 & 3.54 & 2.62 & 2.92 & 0.459 & 12.43 & 6 & 3.5 & 2.6 & 2.9 & 3.155 & 9.00 & 5 \\
\hline $\begin{array}{l}\text { Change of design required } \\
\text { by owners }\end{array}$ & Internal & 23.38 & 3.23 & 2.85 & 2.54 & 0.521 & 12.18 & 7 & 3.2 & 2.9 & 2.5 & 2.936 & 8.82 & 7 \\
\hline $\begin{array}{l}\text { Frequent changes of } \\
\text { design by designers }\end{array}$ & Internal & 21.55 & 3.00 & 2.92 & 2.46 & 0.515 & 11.10 & 8 & 3.0 & 2.9 & 2.5 & 2.816 & 8.03 & 9 \\
\hline $\begin{array}{l}\text { Deficiencies in drawings } \\
\text { and specifications }\end{array}$ & Internal & 17.52 & 2.92 & 2.23 & 2.69 & 0.469 & 8.22 & 9 & 2.9 & 2.2 & 2.7 & 2.704 & 5.95 & 10 \\
\hline Defective design & Internal & 17.29 & 3.38 & 2.08 & 2.46 & 0.444 & 7.68 & 10 & 3.4 & 2.1 & 2.5 & 2.822 & 5.56 & 8 \\
\hline
\end{tabular}

Recommendation from this research discussion, several recommendations are suggested to reduce possible delay risk and to improve the conditions if delay risk is met for a welding construction project: Provide an initial planning and sourcing supplier at the initial project state in examining possible delay risk may be encountered. To evaluate and assess a risk assessment and quality control at the initial project providing comprehensive methods, providing training/experience transfers and development programs to the subcontractors, employee, and staff, communicate with owners, consultants, and contractors with other project parties by regular meetings to ensure that the project progressing well. Although, the time delay leading to cost overrun is very common which it can be eliminated or reduced by applying an appropriate presentation observing and control framework that will be coordinated with all the key perspectives and activities of each phase of the construction project. Hence it would be useful for future research to focus on innovation of welding quality management systems in the comprehensive welding requirement of ISO3834, welding networks model, and applicable use the set mathematic about risk factors, the quality requirement for contribution in welding fabrication industrials.

\section{Acknowledgments}

This research has been supported by King Mongkut's University of Technology Thonburi (KMUTT)for assessment database in International journal publication. Authors are pleased to credit the help of the construction company in Thailand for response in questionnaire and construction experts for interviewed.

\section{References}

[1] D. Arditi, S. Nayak, and A. Damci, "Effect of organizational culture on delay in construction," Int. J. Proj. Manag., vol. 35, pp. 136-147, 2017.

[2] H. Doloi, A. Sawhney, K. C. Iyer, and S. Rentala, "Analysing factors affecting delays in Indian construction projects," Int. J. Proj. Manag., vol. 30, pp. 479-489, 2012.

[3] M. Sambasivan and Y. W. Soon, "Causes and effects of delays in Malaysian construction industry," International Journal of Project Management, vol. 25, no. 5, pp. 517-526, 2007.

[4] S. M. El-Sayegh, "Risk assessment and allocation in the UAE construction industry," Int. J. Proj. Manag., vol. 26, no. 4, pp. 431-438, 2008.

[5] M. Gündüz, Y. Nielsen, and M. Özdemir, "Quantification of delay factors using the relative importance index method for construction projects in Turkey," Journal of Management in Engineering, vol. 29, no. 2, pp. 133-139, 2013.

[6] S. H. Han, S. Yun, H. Kim, Y. H. Kwak, H. K. Park, and S. H. Lee, "Analyzing schedule delay of mega project: lessons learned from Korea Train Express," IEEE Transactions on Engineering Management, vol. 56, no. 2, pp 243-256, 2009.

[7] T. L. Saaty, "Decision making with the analytic hierarchy process," International Journal Services Sciences, vol. 1, no. 1, pp. 83-98, 2008.

[8] S. U. R. Toor and S. O. Ogunlana, "Problem causing delay in major construction project in Thailand," Cons. Management and Economics, vol. 26, no. 4, pp. 395-408, 2008. 
[9] S. S. S. Gardezi, I. A. Manarvi, and S. J. S. Gardezi, "Time extension factors in construction industry of Pakistan," Procedia Engineering, vol. 77, pp. 196 - 204, 2014.

[10] International Monetary Fund (IMF), "Thailand Gross domestic product, current prices," (accessed May 10, 2018).

[11] World Bank Group, "Doing business 2020, Economy profile Thailand," World Bank Group, 2020.

[12] K. Park, H. W. Lee, K. Choi, and S. H. Lee, "Project risk factors facing construction management firms," International Journal of Civil Engineer, pp 1-17, 2017.

[13] P. X. Zou, G. Zhang, and J. Wang, "Understanding the key risks in construction projects in China," Int. J. Proj. Manag., vol. 25, pp. 601-614, 2007.

[14] S. P. Wanjari and G. Dobariya, "Identifying factors causing cost overrun of the construction projects in India," Sädhanā, vol. 41, no. 6, pp. 679-693, 2016.

[15] M. S. Islam and B. T. Suhariadi, "Construction delays in privately funded large building projects in Bangladesh," Asian Journal of Civil Engineering, vol. 19, no. 4, pp. 415-429, 2018.

[16] A. Zeb, A. Qudoos, and H. Hanif, "Identification and analysis of factors affecting machinery in the construction industry of Pakistan," Int. J. of Sciences: Basic and Applied Research, vol. 19, no. 1, pp. 269-278, 2015.

[17] S. Ghosh and J. Jintanapakanont, "Identifying and assessing the critical risk factors in an underground rail project in Thailand: A factor analysis approach," Int. J. Proj. Manag., vol. 22, pp. 633-643, 2004.

[18] S. Demirkesen and B. Ozorhon, "Impact of integration management on construction project management performance," Int. J. Proj. Manag., vol. 35, pp. 1639-1654, 2017.

[19] Risk Management-Risk Assessment Techniques, IEC/ISO 31010:2009, International Organization for Standardization.

[20] R. Rakesh and B. C. Jos, "FMEA analysis for reducing breakdowns of a sub system in the life care product manufacturing industry," Int. J. of Eng. Science and Innovative Technology, vol. 2, no. 2, pp. 218-225, 2013.

[21] D. Gjerdrum and M. Peter, "The new international standard on the practice of risk management - A comparison of ISO 31000:2009 and the COSO ERM framework society of actuaries," Risk Management, vol. 31, no. 21, pp. 8-12, 2011.

[22] F. R. S. D. Santos and S. Cabral, "FMEA and PMBOK applied to project risk management," Journal of Information Systems and Technology Manag., vol. 5, no. 2, pp. 347-364, 2008.

[23] M. Hekmatpanah, A. Shahin, and N. Ravich, "The application of FMEA in the oil industry in Iran: The case of four litre oil canning process of Sepahan Oil Company," African Journal of Business Management, vol. 5, no. 8, pp. 3019-3027, 2011.
[24] W. Song, X. Ming, Z. Wu, and B. Zhu, "A rough TOPSIS approach for failure mode and effects analysis in uncertain environments," Quality and Reliability Engineering International, vol. 30, no. 4, pp. 473-486, 2013.

[25] A. Al-Kharashi and M. Skitmore, "Causes of delays in Saudi Arabian public sector construction projects," Construction Management and Economics, vol. 27, no. 1, pp. 3-23, 2009.

[26] L. Le-Hoai, Y. Dai Lee, and J. Y. Lee, "Delay and cost overruns in Vietnam large construction projects: A comparison with other selected countries," KSCE Journal of Civil Eng., vol. 12, no. 6, pp 367-377, 2008.

[27] T.-C. Tsai and M.-L. Yang, "Risk management in the construction phase of building projects in Taiwan," Journal of Asian Architecture and Building Engineering, vol. 8, no. 1, pp. 143-150, 2018.

[28] R. K. T. Akogbe, X. Feng, and J. Zhou, "Importance and ranking evaluation of delay factors for development construction projects in Benin," KSCE Journal of Civil Eng., vol. 17, no. 6, pp. 1213-1222, 2013.

[29] M. M. Marzouk and T. I. El-Rasas, "Analyzing delay causes in Egyptian construction projects," Journal of Advanced Research, vol. 5, pp. 49-55, 2014.

[30] A. Olechowski, J. Oehmen, W. Seering, and M. BenDaya, "The professionalization of risk management: What role can the ISO 31000 risk management principles play?," Int. J. Proj. Manag., vol. 34, pp. 1568-1578, 2016.

[31] J. Kang, L. Sun, H. Sun, and C. Wu, "Risk assessment of floating offshore wind turbine based on correlation-FMEA," Ocean Engineering, vol. 129, pp. 382-388, 2017.

[32] Y. Gajare, P. Attarde, and D. K. Parbat, “Assessment of significant causes and effects of delays on the projects completion period," International Journal of Modern Trends in Engineering and Research, vol. 2, no. 2, pp. 88-93, 2015.

[33] A. Aumpiem and A. Prateepasen, "FMEA for risk assessment in discoloration pipe welding," in International Conference on Recent Trends in Engineering and Technology, Bangkok, Thailand, 2017, pp. 232-237.

[34] A. K. Pandey and R. K. Sharma, "FMEA-base interpretive structural modelling approach to model automotive supply chin risk," Int. J. Logistics Systems and Management, vol. 27, no. 4, pp. 395-417, 2017.

[35] E. A. Gyasi, P. Kah, and J. Martikainen, "Welding management as a tool for innovative, competitive and sustainable manufacturing: Case study - West Africa," Int. J. of Development and Sustainability, vol. 3, no. 8, pp. 1782-1793, 2014.

[36] D. J. Thomas, "Analyzing the failure of welded steel components in construction systems," J. Fail. Anal. and Preven., vol. 18, pp. 304-314, 2018.

[37] N. A. McPherson, "Welding issues for ship structures," Journal of Marine Engineering \& Technology, vol. 9, no. 3, pp. 31-41, 2010. 
[38] J. Kozak and Z. Gorski, "Fatigue strength determination of ship structural joints," Polish Maritime Research, vol. 2, no. 69, vol 18, pp. 28-36, 2011.

[39] J. U. D. Hatmoko and R. R. Khasani, "Mapping delay risks of EPC projects: A case study of a platform and subsea pipeline of an oil and gas project," IOP Conference Series: Materials Science and Engineering, vol. 598, no. 1, p. 012095, 2019.

[40] M. H. Fallahnejad, "Delay causes in Iran gas pipeline projects," Int. J. Proj. Manag., vol. 31, pp. 136-146, 2013.

[41] D. P. Fang, M. G. Li, P. S. W. Fong, and L. Y. Shen, "Risks in Chinese construction market: Contractors' perspective," J. Construction Engineering and Management, vol. 130, no. 6, pp. 853-861, 2004.

[42] M. S. B. A. Abd El-Karim, O. A. Mosa El Nawawy, and A. M. Abdel-Alim, "Identification and assessment of risk factors affecting construction projects," HBRC Journal, vol. 13, no. 2, pp. 202-216, 2017.

[43] R. L. Armstrong, "The midpoint on a five-point Likert-type scale," Perceptual and Motor Skills, vol. 64, no. 2, pp. 359-362, 1987.

[44] B. G. Hwang, X. Zhao, and L. P. Toh, "Risk management in small construction projects in Singapore: Status, barriers and impact," Int. J. Proj. Manag., vol. 32, pp. 116-124, 2014.

[45] N. Xiao, H. Z. Huang, Y. Li, L. He, and T. Jin, "Multiple failure modes analysis and weighted risk priority number evaluation in FMEA," Engineering Failure Analysis, vol. 18, pp. 1162-1170, 2011.

[46] M. S. Bajjou and A. Chafi, "Identifying and managing critical waste factors for lean construction projects, Engineering Management Journal, vol. 32, no. 1, pp. 2-13, 2019.

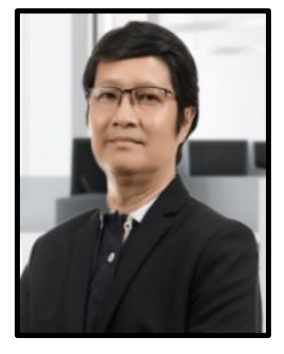

Asa Prateepasen received the B.Eng. in Industry Engineering and M.Eng. in Mechanical Engineering from King Mongkut's University of Technology Thonburi, Thailand, in 1984 and 1992, respectively. He received the D.Eng. in System Engineering, Brunel University, United Kingdom, in 2001.

He has been working and research in non-destructive testing in King Mongkut's University of Technology Thonburi, and lead of acoustic emission and advance non-destructive testing section. About 20 years, he has more experience in non-destructive testing and extends his field in construction management industry.

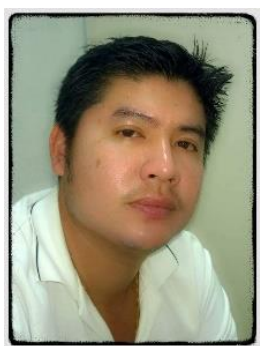

Adisak Aumpiem was born in Thailand in 1979. He received the B.Eng. degree in Welding Technology for Mongkut's University of Technology North Bangkok (KMUTNB) in 2005 and the M.Eng. degree in Welding engineering from King Mongkut's University of Technology Thonburi (KMUTT), Thailand, in 2009.

Since 2009, he was worked in welding \& NDE industry and currently is a welding coordintor in an offshore construction company. His research interests including Welding quality systems/controls, Risk management in project. 